\title{
Rajaviiva katoaa
}

\author{
Pirjo Lambert
}

\author{
Väitöskirjatutkimuksessani olen lähestynyt ammatillisten \\ oppilaitosten opettajien työtä opettajankoulutuksen \\ kautta. Rinnakkaisina prosesseina kulkevat näin ollen \\ opettajankoulutuksen sekä opettajan työn kehittäminen. \\ Kysymyksessä on omaa työtäni koskevasta tutkimus- ja \\ kehittämisprojektista, jossa olen nostanut opettajan työn \\ lähikuvaan opettajankoulutustyötä tekemällä, sitä rinnan \\ tutkimalla ja kehittämällä.
}

\begin{abstract}
Ammatillisessa koulutuksessa on meneillään laajamittainen, tutkinto- ja opetussuunnitelmajärjestelmää koskettava uudistustyö. Ammattikorkeakoulujärjestelmän kehittämisen lisäksi kyse on koko ammatillisen perusopetuksen uudelleenjärjestämisestä ja sen toteuttamisesta yhteistyössä oppilaitosten ja työelämän organisaatioiden kesken. Kehittämistyössä päätösvalta ja vastuu on siirtynyt yhä enemmän valtakunnallisista keskusvirastoista oppilaitostasolle.
\end{abstract}

Uudistusten myötä opettajan työ on yhdessä suunnassa siirtynyt yhä enemmän ajan, paikan ja instituutioiden rajat ylittäviin avoimiin oppimisympäristöihin (esim. Achtenhagen 1992; Helakorpi \& Olkinuora 1995; Kauppi 1998; Miettinen, Isokangas \& Peisa 1997) ja toisessa suunnassa "uuteen opettajuuteen" on liitetty näkemys omaa ja koko koulun työtä tutkivasta ja kehittävästä opettajasta (esim. Helakorpi 1995; Niemi 1996; Ojanen 1996).

Opettajan työssä tapahtuneiden muutosten myötä on myös opettajan asiantuntijuus noussut uudelleenpohdinnan kohteeksi. Pääsääntöisesti tätä asiantuntijuutta on hahmotettu "pystysuuntaisella" ulottuvuudella, yksilöasiantuntijan kehit- tymisenä noviisista ekspertiksi (esim. Berliner 1986; Kennedy 1987; Leinhardt 1988; Ropo 1991) tai etsimällä taitavan opettajan ominaisuuksia (esim. Sternberg \& Horvath).

Uusien oppilaitosmuotojen lisääntyminen sekä oppilaitosten ja työelämän välisen yhteistyön kehittäminen edellyttävät opettajalta kuitenkin toimimista useissa rinnakkaisissa konteksteissa. Ammatillisten oppilaitosten opettajat työskentelevät samanaikaisesti monissa asiantuntijaryhmissä ja yhteistyötilanteissa, jolloin tämä "monessa mukana oleminen" muotoutuu yhä enemmän keskusteluun perustuvaksi asiantuntijatyöksi. Opettajat joutuvat mukaan uusiin ympäristöihin ja vuorovaikutteisiin ongelmanratkaisutilanteisiin, joissa omalle alueelle rajoittunut, tehtävien ja taitojen yksilölliseen hallintaan perustuva asiantuntijuus ei enää riitä. Tarvitaan eri ammattialojen ja henkilöryhmien välistä vuoropuhelua ja eri näkökulmia edustavien henkilöiden tietojen yhdistämistä. Asiantuntijuuden ymmärtäminen edellyttää yhä enemmän sen "vaakasuoran", vuorovaikutteisen ja yhteistoiminnallisen ulottuvuuden hahmottamista. 
Ammatillisessa opettajankoulutuksessa tapahtuva tutkimus- ja kehittämistoiminta tuottaa välineitä opettajan työhön ja oppilaitosten toiminnan kehittämiseen. Miten opettajankoulutus toimii muutosvoimana, riippuu oleellisesti siitä, millaiset yhteydet sillä on oppilaitosten ja niihin kytkeytyvien työelämän organisaatioiden toimintaan.

Kun pohditaan, miten opettajankoulutuksessa opitut tiedot ja taidot otetaan käyttöön ammatillisissa oppilaitoksissa ja muissa koulutusorganisaatioissa, puhutaan yhdestä opetuksen "ikuisuusongelmasta", siirtovaikutuksesta. Ammatillisen opettajankoulutuksen nykyiset toimintamallit näyttävät heijastavan joko sisältöihin tai sosiaalisiin prosesseihin kohdistuvia lähestymistapoja siirtovaikutuksen tuottamiseen.

$\mathrm{K}^{\mathrm{s}}$ eskeisenä opettajankoulutuksen ohjelmissa äyttäytyy tänä päivänä opetusharjoittelu, joka pääasiassa sisältää oppituntien seuraamista ja harjoitustuntien pitämistä. Opettajankoulutussysteemin vanhin elementti, 1800-luvulta peräisin oleva pätevöittämis- ja kontrollimekanismina toiminut "opetusnäyte" on jättänyt jälkensä koulutusohjelmiin (Miettinen 1993). Siirtovaikutuksen näkökulmasta tässä mallissa yksittäinen opiskelija toimii tiedon siirtäjänä toiseen kontekstiin, jolloin tieto pysyy samana, mutta sen käyttökonteksti muuttuu.

$\mathrm{T}_{1}$ oinen keskeinen toimintamalli opettajankoulutuksessa on projektityöskentely. Opettajaopiskelijat työskentelevät yhdessä pätevien opettajien kanssa laajoissa, monitieteisissä tutkimusprojekteissa, joilla opiskelun painopistettä on samalla siirretty lähemmäksi työelämän haasteita ja luotu samalla tätä kautta uusia, avoimempia oppimisympäristöjä. Siirtovaikutuksen näkökulmasta tässä mallissa korostetaan tietojen ja taitojen tilannesidonnaisuutta ja niiden uudelleenkonstruoimisen välttämättömyyttä jokaisessa kontekstissa. Oppimisen katsotaan parhaiten tapahtuvan, ei tietojen siirtymisenä, vaan oppijan kehittymisenä noviisista ekspertiksi opetustyöhön osallistumalla (Lave 1988).

Tässä on nähtävissä kaksijakoinen kehitys: ope-

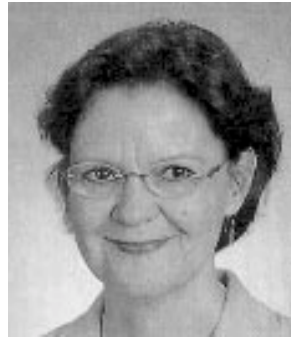

Pirjo Lambert

tusharjoittelussa harjoitellaan opettamista ja oppimisen ohjaamista ja projekteissa tutkitaan ja kehitetään oppilaitosten opetustyötä. Ongelmaksi näyttää muodostuvan yhtäältä se, että oppimisen kohteena oleva opetuksellinen vuorovaikutus rajoittuu vain opettajan ja opiskelijan väliseksi, useimmiten luokkahuonekontekstiin sidotuksi vuorovaikutukseksi ja toisaalta se, että kehittämistyö ei laajene oppilaitosyhteisöihin, vaan rajautuu siellä opettajaopiskelijan projektin "sisälle" ja päättyy opiskelun loppuessa (Lambert 1995).

$\mathrm{O}$ pettajankoulutuksessa tuotettuja uusia ideoita, ratkaisuja ja malleja on vaikea kehittää eteenpäin, mikäli myös kehittämistyötä ei nähdä kommunikatiivisena prosessina ja mikäli näitä prosesseja ei oteta systemaattisen tutkimuksen ja kehittämisen kohteeksi. Tarvitaan siis uusia siirtovaikutuksen välineitä, jolloin siirtovaikutuksen tuottamisessa ei keskitytä vain sisältöihin tai sosiaalisiin prosesseihin, vaan niiden molempien yhtäaikaiseen kehittämiseen.

Olen lähestynyt tutkimuksessani kysymystä Yrjö Engeströmin (1998) esittämän, kulttuurihistorialliseen toiminnan teoriaan (Engeström 1987; Leontjev 1977) pohjautuvan kehittävän siirtovaikutuksen idean avulla. Näkemys jaetusta tai hajautetusta kognitiosta (Cole \& Engeström 1993 ) uudelleenmäärittää oppimisen analyysiyksiköksi välineiden, sääntöjen, yhteisön ja työnjaon välittämän kollektiivisen toimintajärjestelmän. Oppimisen siirtovaikutus tapahtuu vuorovaikutuksessa kollektiivisten toimintajärjestelmien välillä ja se nähdään tällöin yhteistoiminnallisina, myös konflikteja sisältävinä kohtaami- 


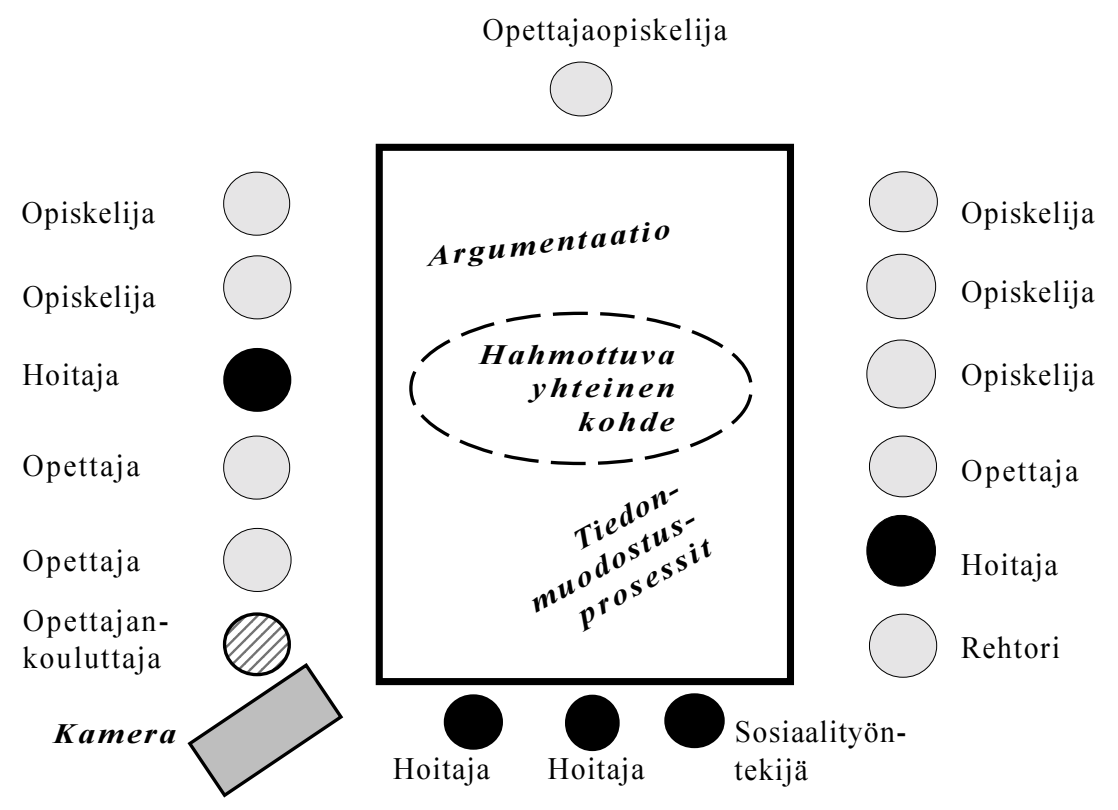

Kuvio1. Oppimisstudio vuorovaikutuksellisten prosessien mahdollistajana

sina ja neuvotteluina erilaisten kulttuurikontekstien välillä.

Väitöskirjatyössäni on kysymys uuden toimintamallin kehittelystä ja kokeilusta kehittävän siirtovaikutuksen tuottamiseksi ammatillisessa opettajankoulutuksessa.

Kokeilu toteutettiin terveys- ja sosiaalialan ammatillisessa opettajankoulutuksessa Helsingin sairaanhoito-opistossa vuoden 1995 aikana. Opettajankoulutuksen kokeiluopetussuunnitelma perustui Engeströmin $(1987$; 1994) ekspansiivisen oppimisen malliin ja tarkoituksena oli laajentaa toiminnan kohdetta yksittäisen opettajaopiskelijan oppimisesta oppilaitosyhteisöjen kollektiiviseen oppimiseen.

Opettajankoulutuksen interventiona toteutettiin terveys- ja sosiaalialan oppilaitoksissa uudenlainen koulutus- ja kehittämistilaisuus, "oppimisstudio“ (kuvio 1). Tähän opettajaopiskelijan kehittämishankkeen pohjalta järjestettyyn tilaisuuteen pyrittiin saattamaan samanaikaisesti yhteen kaikki ne tahot, joita opettajaopiskelijan tutkimus tai kehittämishanke koski. Tilaisuuteen kutsuttiin eri ammatti- ja henkilöryhmiä opettajankoulutuksesta, terveys- ja sosiaalialan oppilaitoksista ja näiden opiskelijoiden harjoittelupaikkoina toimivista työelämän organisaatioista.

Oppimisstudio tarjosi nyt mahdollisuuden opettajankoulutuksessa tuotettujen välineiden ja opettajaopiskelijoiden hankkeissa saatujen tulosten aktiiviseen ja kollektiiviseen tulkintaan, muuntamiseen ja uudelleenrakentamiseen em. organisaatioiden rajoja ylittävässä vuorovaikutusprosessissa.

Tutkimuksen tehtävänä oli selvittää, miten oppimisstudiot käynnistivät innovatiivista oppimista oppilaitosyhteisöissä. Olen kuvannut keskustelun kohteen hahmottumista analysoimalla rajanylitystilanteessa tapahtuvaa argumentaatiota ja tiedonmuodostuksen prosesseja (kuvio 1) sekä tarkastelemalla oppimisstudioissa syntyneiden innovaatioiden käynnistymistä oppilaitoksissa.

Tutkimuksen pääaineistona olivat 11 oppimisstudion videonauhoitukset, oppimisstudioihin osallistuneiden eri osapuolten ryhmähaastattelut sekä opettajaopiskelijoiden haastattelut $2 \mathrm{kk}$ oppimisstudion jälkeen. 


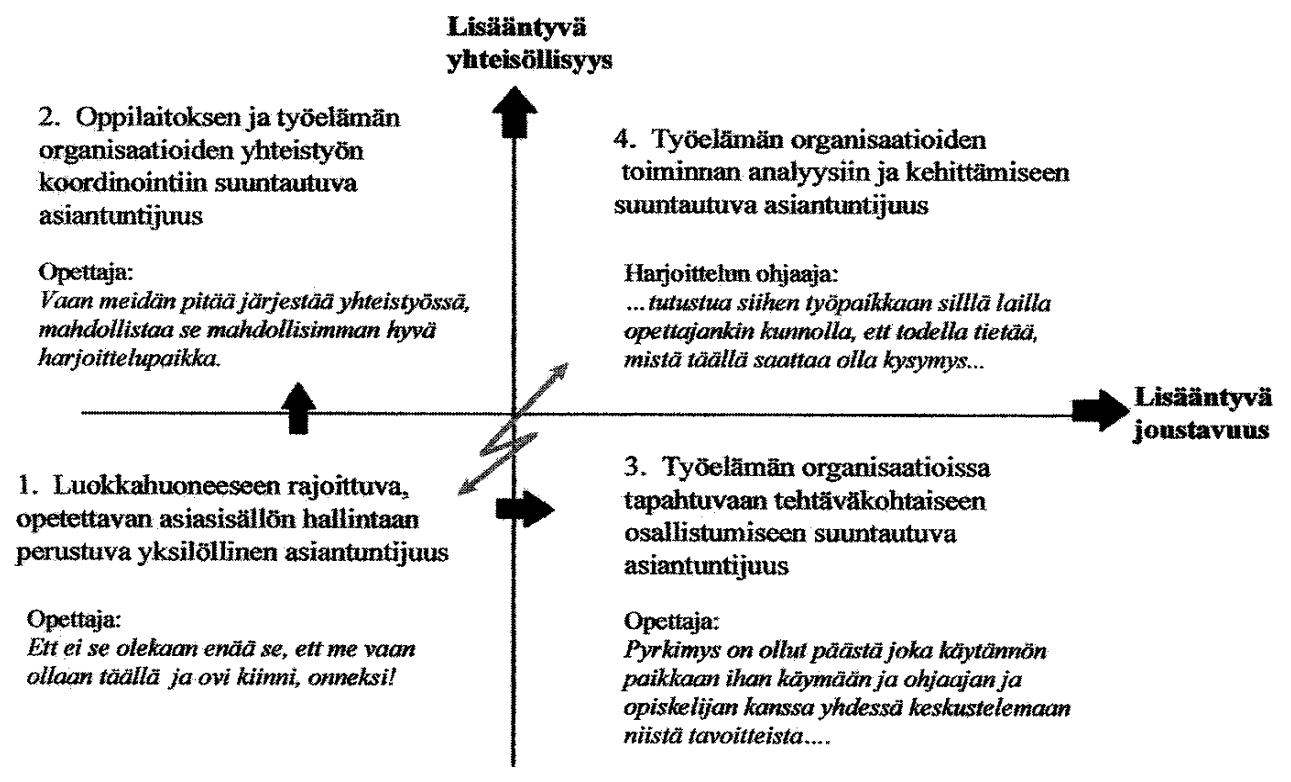

Kuvio 2. Hypoteesi asiantuntijayhteistyön organisoitumisen muutoksesta terveys- ja sosiaalialan oppilaitosten opettajan työssä

$\mathrm{U}_{\mathrm{w} \text { iv }}^{\mathrm{w}}$ uden toimintamallin käyttöönottoon sisältyi sen törmääminen opettajankoulutuksen näytetunteihin perustuvaan entiseen toimintatapaan. Törmäykset tapahtuivat kolmella tavalla: keskusteluasetelmien muodostumisessa, jolloin oppilaitosten opiskelijat jäivät monissa oppimisstudioissa "sivustakatsojiksi"," opettajaopiskelijoiden keskustelun ohjaamisessa, jolloin opettajaopiskelijat eivät aina pystyneet säätelemään osapuolten rooleja keskustelussa ja opettajankoulutuksen suhteissa muihin organisaatioihin, jolloin opettajankoulutusta ei aina hahmotettu keskustelussa yhteistyökumppaniksi.

Oppimisstudiot toimivat myös innovatiivisen, kollektiivisen ja rajoja ylittävän oppimisen virittäjinä. Keskustelut oppimisstudioissa muotoutuivat yhteistä kohdetta etsiväksi ja rakentavaksi ekspansiiviseksi oppimiseksi (Engeström 1999), jolloin askeleittain etenevän, kollektiivisen tiedonmuodostuksen tuloksena syntyi uudenlaisia opettajien, opiskelijoiden ja harjoittelun ohjaajien yhteistyöhön perustuvia toimintamalleja. Yhteisen kohteen kehittymisessä tärkeäksi muodostuivat yhteisten perspektiivien (Holland \& Reeves 1995) ja eri konteksteille yhteisten rajakohteiden (Star 1998) muotoutuminen.
Tutkimuksessa tekemieni analyysien pohjalta tarkensin opettajankoulutuksessa muodostettua ammattiopetuksen lähikehityksen vyöhykettä. Kuvasin asiantuntijayhteistyön organisoitumisen muutosta terveys- ja sosiaalialan oppilaitosten opettajien työssä toiminnan yhteisöllisyyden ja joustavuuden ulottuvuuksilla (kuvio 2).

Asiantuntijayhteistyön päämuotoina hahmottuivat 1)luokkahuoneeseen rajoittuva, opetettavan asiasisällön hallintaan perustuva yksilöllinen asiantuntijuus, 2)oppilaitoksen ja työelämän organisaatioiden yhteistyön koordinointiin suuntautua asiantuntijuus, 3)työelämän organisaatioissa tapahtuvaan tehtäväkohtaiseen osallistumiseen perustuva asiantuntijuus sekä 4)työelämän organisaatioiden toiminnan analyysiin ja kehittämiseen suuntautuva asiantuntijuus.

$\mathrm{T}$ utkimukseni pohjalta näyttää siltä, että vaihtoehtoisina kehityssuuntina tulevat esiin asiantuntijuuden kehittäminen, jossa yhteistyön tarkoituksena on eri koulutusohjelmista vastaavien opettajien ja harjoittelupaikoissa toimivien ohjaajien töiden koordinointi yhteen - tai asiantuntijuuden kehittäminen, jossa osallistumiskehyksenä on opiskelijoiden harjoittelun 
ohjaus ja arviointi opetussuunnitelman pohjalta.

Neljäs asiantuntijayhteistyön muoto tuli oppimisstudioissa esiin vasta "ituina". Työelämän edustajat eivät pitäneet riittävinä em. osallistumiskehyksiä, vaan heidän toiveensa kohdistuivat opettajien osallisuuteen myös harjoittelupaikkoina toimivien organisaatioiden ja yhteisöjen toiminnassa. Tällaisen asiantuntijayhteistyön muoto korostaa asiantuntijuuden "vaakasuoraa" ulottuvuutta, jonka keskeisenä piirteinä nähdään rajanylitykset ja monikontekstisuus (Engeström ym. 1995), jolloin asiantuntijat ovat osallisena lukuisissa eri konteksteissa. Uusien terveys- ja sosiaalialan ammattien ja tutkintojen muodostuminen ja kehittyminen edellyttävät opettajien osallistumista ammattipätevyyden tutkimiseen yhteistyössä terveys- ja sosiaalialan opiskelijoiden ja työntekijöiden kanssa. Opettajien asiantuntijayhteistyö voisikin näin ollen ulottua yhä enemmän harjoittelupaikkoina toimivien organisaatioiden toimintakäytäntöjen analyysiin ja kehittämiseen. Edelläkuvatut muut yhteistyövaihtoehdot eivät riitä kehittyvän ammattipätevyyden tuottamiseen. Välineitä tällaiseen yhteistyöhön ei kuitenkaan vielä ole. Luokkahuoneopetuksen mallissa tarvittavat ja edelleen pitkälti käytössä olevat välineet eivät riitä horisontaalisen asiantuntijuuden kehittämiseen. Opettajien työssä tarvitaan uudenlaisia yhteistoiminnallisen ja vuorovaikutteisen aiantuntijayhteistyön välineitä.

$\mathrm{T}_{k}$ utkimukseni pohjalta on pääteltävissä, että kehittävän siirtovaikutuksen tuottaminen edellyttää yhteistyötä ja oppimista estävien rajojen ylittämistä ja uusien rajanylitysten välineiden kehittämistä. Tässä tutkimuksessa saatujen tulosten jatkokehittelyä ajatellen konkretisoin nämä erilaisiksi ammatillisen opetuksen suunnittelutehtäviksi (Lambert, käsikirjoitus).

Ensinnäkin, haasteena on kehittää uusia rajanylityspaikkoja (esim. Wenger 1998), joissa opiskelijat voivat toimia välittäjinä ja rajanylittäjinä koulutusorganisaatioiden ja työpaikkojen välillä. Oppimisstudion ideaa voidaan hyvin muuntaa myös ammatillisten koulutusohjelmien käyttöön. Tällaiset rajanylityspaikat mahdollistavat rajanylityksiin tarvittavien välineiden kehittämisen. Toiseksi, rajanylitykset tulisi ottaa opettajien ja opiskelijoiden yhteisiksi tutkimus- ja oppimistehtäviksi (Hakkarainen 1993). Tämä edellyttää tapahtumien aktiivista tallentamista ja niiden kriittistä erittelyä. Opiskelijoille rajanylitystilanteissa toimiminen on monasti uusi ja vaikea tehtävä. He ovat kuitenkin tärkeitä muutosagentteja. Kolmanneksi opiskelijoita tulisi myös ohjata toimimaan rajanylittäjinä ja rajanylityksiin soveltuvien välineiden käyttäjinä.

Opettajakoulutuksen tulee ottaa aktiivinen rooli uudenlaisen oppimisen ja asiantuntijuuden tuottajana. Oppimisstudio toimintamallina tarjoaa tähän yhden varteenotettavan vaihtoehdon. Tässä kokeilussa saadut tulokset innovatiivisesta oppimisesta ja kollektiivisesta tiedonmuodostuksesta voivat toimia myös jatkossa oppimisstudioiden kehittämistä ja toimintamallin vakiinnuttamista suuntaavina lähtökohtina. Rajat eivät koskaan lopu eivätkä ne katoa itsestään. Rajaviiva katoaa vain yhteisen työn tuloksena.

\section{Lähteet}

ACHTENHAGEN, F. \& John, E. G. (toim) (1992) Mehrdimensionale Lehr-Lern-Arrangements. Innovationen in der Kaufmännischen Aus- und Weiterbildung. Wiesbaden: Der Gabler Verlag.

Berliner, D. C. (1986) In pursuit of the expert pedagogue. Educational Researcher 15, 7, 5-13.

COLE, M. \& Engeström Y. (1993) A cultural-historical approach to distributed cognition. Teoksessa G. Salomon (toim.) Distributed Cognitions: Psychological and educational considerations. Cambridge: Cambridge University Press

ENGESTRÖM, Y. (1987) Learning by expanding: An activity theoretical approach to developmental research. Helsinki: Orienta-Konsultit Oy.

ENGESTRÖM, Y. (1994) Training for Change. New approach to instruction and learning in working life. ILO. Geneva

ENGESTRÖM, Y. (1998) Reconceptualizing transfer and remodeling internship. Esitelmämoniste. COST Action 11: European Cooperation in the field of scientific and technical research. Flexibility, transferability and mobility as targets of vocational education and training. Seminaari Helsingissä $12-13.10 .1998$

ENGESTRÖM, Y. (1999) Innovative learning in work teams: Analyzing cycles of knowledge creation in practice. Teoksessa: Y. Engeström, R. Miettinen \& R-L. Punamäki (toim.) Perspectives on activity theory. Cambridge: Cambridge University Press. 
ENGESTRÖM, Y. \& Engeström, R. \& Kärkkäinen, M. (1995) Polycontextuality and boundary crossing in expert cognition: Learning and problem solving in complex work activities. Learning and instruction 5, 319-336.

HAKKARAINEN, P. (1993) Oppiminen korkeakouluopetuksen haasteena. Kasvatus 26, 5, 473 - 481.

HELAKORPI, S. (1995) Foundations of vocational teacher education curriculum. Teoksessa J. Lasonen \& M-L. Stenström (toim.) Contemporary issues of occupational education in Finland. Jyväskylän yliopisto. Kasvatustieteen tutkimuslaitos.

HELAKORPI, S. \& Olkinuora, A. (1997) Asiantuntijuutta oppimassa. Ammattikorkeakoulupedagogiikkaa. Porvoo: WSOY.

HOLLAND, D. \& Reeves, J. R. (1994) Activity Theory and the View from Somewhere: Team Perspectives on the Intellectual Work of Programming. Mind, Culture and Activity. An International Journal 1, 1-2, 8-24

KAUPPI, A. (1998) Curriculum Development for integrating Work and Learning. Lifelong Learning in Europe 2, 76-85.

KENNEDY, M. M. (1987) Inexact sciences: Professional education and development of expertise. Teoksessa E. Z. Rothkopf (toim.) Review of Re-search in Education, Vol. 14, 133-167. Washington, DC: American Educational Research Association

LAMBERT, P. (1995) Terveydenhuolto-oppilaitosten opettajien työn kehittäminen. Kehittävän työntutkimuksen sovellus ammatillisessa opettajankoulutuksessa. Helsingin yliopisto. Opettajankoulutuslaitos. Lisensiaatintutkimus. Helsinki: Educa-instituutti.

LAMBERT, P. Developing Transfer in Vocational Teacher Education. Artikkelikäsikirjoitus.

Lave, J. (1988) Cognition in practice: Mind, mathematics, and culture in everyday life. Cambridge: Cambridge University Press.

LEINHARDT, G. (1988) Situated knowledge and expertise in teaching. Teoksessa: J. Calderhead (toim.) Teachers' professional learning, 146-168. London: Falmer Press

LEONTJEV, A. N. (1977) Toiminta, tietoisuus, persoonallisuus. Helsinki: Kansankulttuuri Oy.

Miettinen, R. (1993) Oppitunnista oppimistoimintaan. Tutkimus opetuksen ja opettajankoulutuksen kehittämisestä Suomen Liikemiesten Kauppaopistossa vuosina 1986-1991. Tampere: Gaudeamus.

MIETTINEN, R., Isokangas, J. \& Peisa, S. (1997) Yrityksen perustamisen ja toiminnan tutkiminen partneriyrityksen käyttö kaupallisessa koulutuksessa. Teoksessa: Työn muutos ja oppiminen. Aikuiskasvatuksen 38. vuosikirja. Kansanvalistusseura ja Aikuiskasvatuksen Tutkimusseura.

NIEMI, H. (1996) Itsenäistä ajattelua vai kuuliaista tottelevaisuutta? Opettajan ammatti muutoksessa. Teoksessa: S. Ojanen (toim.) Tutkiva opettaja. Helsingin yliopiston Lahden tutkimus- ja koulutuskeskus.

OJANEN, S. 1996. Mihin tarvitaan tutkivaa opettajaa? Teoksessa: S. Ojanen (toim.) Tutkiva opettaja. Helsingin yliopiston Lahden tutkimus- ja koulutuskeskus

ROPO, E. (1991) Opettajaeksperttiyden kehittymi- nen - tutkimustuloksia ja näkökulmia. Aikuiskasvatus 11, 3, 153-163.

STAR, S. L. (1989) The structure of ill-structured solutions: Boundary objects and heterogeneous distributed problem solving. Teoksessa L. Gasser \& M N. Huhns (toim.) Readings in Distributed artificial intelligence 3. Menlo Park, CA: Morgan Kaufmann.

STERNBERG, R. J. \& Horvath, J. A. (1995) A prototype View of Expert Teaching. Educational Researcher $24,6,9-17$

WEGNER, E. (1998) Communities of practice. Learning, meaning, and identity. Cambridge: Cambridge University Press.

Lectio praecursoria. Pirjo Lambert väitteli Helsingin yliopiston kasvatustieteellisessä tiedekunnassa 18.6.1999 tutkimuksellaan Rajaviiva katoaa. Innovatiivista oppimista ammatillisen opettajankoulutuksen, oppilaitosten ja työelämän organisaatioiden yhteistyönä. Vastaväittäjänä oli professori Pentti Hakkarainen Oulun yliopistosta. 